\title{
COMPARISON OF THE EFFECTIVENESS OF THERAPY IN HYDRODISSECTION INJECTION USING ULTRASONOGRAPHY GUIDENCE BETWEEN NORMAL SALINE AND TRIAMCINOLONE IN CARPAL TUNNEL SYNDROME PATIENTS
}

\author{
Widodo Mardi Santoso ${ }^{1}$, Rodhiyan Rakhmatiar ${ }^{1,}$ Alidha Nur Rakhmani ${ }^{2}$, Muhammad Ghalvan Sahidu ${ }^{1}$ \\ Correspondence: allansah87@gmail.com \\ ${ }^{I}$ Department of Neurology Faculty of Medicine Brawijaya University, Malang, Indonesia. \\ ${ }^{2}$ Division of Public Health Sciences Faculty of Medicine Brawijaya University, Malang, Indonesia.
}

\section{Article History: \\ Received: January 22, 2019 \\ Accepted: May 7, 2019 \\ Published: Januari 1, 2020}

\section{Cite this as:}

Santoso WM, Rakhmatiar $R$ Reakhmani AN, Sahidu MG.

Comparison of the effectiveness of therapy in hydrodissection injection using ultrasonography guidence

between normal saline and triamcinolone in carpal tunnel syndrome patients. Malang Neurology Journal; 2020.6: 5-10

http://dx.doi.org/10.21776/ub.mnj.202 0.006 .01 .2

\section{ABSTRACT}

Background: Carpal tunnel syndrome (CTS) is a peripheral nerve lesion because of the nontraumatic mechanism or a pressure or entrapment of the median nerve under the transverse ligament (flexor retinaculum). Hydrodisection is used for adhesiolysis to eliminate adhesion and release the median nerve from the retinaculum and connective tissue around it and avoid injury to the nerves.

Objective: Compare the effectiveness of hydrodisection injection therapy using an ultrasound guide between normal saline and triamcinolone in patients with carpal tunnel syndrome.

Methods: Experimental study was carried out in the outpatient clinic of the hospital Dr. Saiful Anwar Malang from August 2018 to October 2018. A total of 30 patients. All study subjects were subjected to NPS, FSS, SSS scoring compared to before and 4 weeks after injection of hydrodisection and compared the effectiveness of injection agents.

Results: NPS before and after triamcinolone injection (sig 0.000; p <0.05), FSS (sig 0.020; p <0.05), and SSS (sig 0.001; $\mathrm{p}<0.05$ ). NPS before and after injection of normal saline $0.9 \% \mathrm{NaCl}$ (sig $0.001 ; \mathrm{p}$ $<0.05$ ), FSS ( $\operatorname{sig} 0.005 ; \mathrm{p}<0.05$ ), and SSS ( $\operatorname{sig} 0,000 ; \mathrm{p}<0.05$ ). NPS between triamcinolone injection results and normal saline $0,9 \% \mathrm{NaCl}$ (sig $0.341 ; \mathrm{p}<0.05$ ), FSS (sig $0.425 ; \mathrm{p}<0.05$ ), SSS (sig 0.350; $<0.05)$.

Conclusion: There no significant difference between injection of hydrodisection USG guiding with triamcinolone and normal saline $0,9 \% \mathrm{NaCL}$ to reduce symptom CTS. Both of injection hydrodisection USG guiding has more or less the same effectiveness in treatment of carpal tunnel syndrome.

Keywords: CTS, Hydrodisection, NPS, FSS, SSS

\section{Introduction}

Carpal tunnel syndrome (CTS) is a peripheral nerve lesion because of the nontraumatic mechanism that is often encountered. CTS is a neuropathy, which is caused by a pressure or entrapment of the median nerve under the ligament of carpi transversum (flexor retinaculum). One of the most serious diseases of the median nerve is entrapment neuropathy, better known as Carpal Tunnel Syndrome. Carpal Tunnel Syndrome (CTS) is a collection of symptoms caused by compression of the median nerve on the wrist. This disease is often found in daily practice. The term carpal tunnel is used because the area passed by the median nerve is shaped like a tunnel and is surrounded by eight bones called the carpal bone. In this syndrome symptoms arise due to entrapment of the median nerve, which runs through the tunnel. ${ }^{1,2}$

Most patient seek treatment after symptoms arise. Some excessive and repetitive hand activities such as flexion and extension of the wrist will cause traps in the median nerve.
The therapeutic methods for various carpal tunnel syndrome (CTS), starting with non-surgical methods (physiotherapy, psychological approaches, pharmacotherapy, injection) to surgical (surgery). When the non-surgical method is indicated, injection of local corticosteroids into the carpal tunnel can be used to reduce pain and tingling. There is more evidence that the use of needles with a sonographic guide in general results in a significant increase. The use of sonography was successfully used in the injection of carpal tunnel syndrome with excellent results. ${ }^{2,3,4}$

The definition of hydrodisection depending on the procedure or action used for. Previously described in reoperative therapy, hydrodisection was used for adhesiolysis with the use of saline in the area of operation. This aims to help eliminate adhesion. Hydrodisection is widely used in many ways. The hydrodisection process in CTS treatment to insert and direct the needle around the median nerve. The hope of this hydrodisection injection is to release the median nerve from the retinaculum and the surrounding connective tissue. Then the main purpose of hydrodisection is to avoid 
accidental direct injection and nerve injury. The secondary goal is to separate the adhesion or obstruction of potential soft tissue from the nerves that can cause clamping. ${ }^{5}$

\section{Methods}

This research is experimental research. This research was carried out at the outpatient polyclinic in Dr. Saiful Anwar Hospital Malang. This research was conducted in 3 months in August-September 2018.

The study population was all patients with carpal tunnel syndrome at the outpatient polyclinic in Dr. Saiful Anwar Hospital Malang. The study sample was a study population that have the inclusion and exclusion criteria.

This study had inclusion criteria for patients who had neuropatic pain complaints (paresthesia, hypesthesia, burning sensation) in the distribution area of median nerve innervation, felt complaints at least 3 months, EMG examination was performed.

While the exclusion criteria for this study were symptomatic carpal tunnel syndrome (diabetes, thyroid disease, rheumatic disease), age less than 18 years, pregnancy, had previously received CTS injection, fracture or deformity in the wrist, suffered from other polyneuropathy, had never received pharmacotherapy oral, Obtained muscle atrophy or motor weakness.

The research variables to be analyzed in this study include injection of hydrodisection with the results of each of the CTS scoring results, namely numerical pain scale (NPS) and boston carpal tunnel questionnaire (BCTQ) score.

Numeric Pain Scale (NPS) is one of the tools for scoring pain, consisting of 10 numbers, namely numbers 0 to 10 . A score of 0-3 means mild pain or no pain, score 4-7= moderate pain, 8-10 score $=$ severe pain .

The Boston carpal tunnel questionnaire (BCTQ) is one of the CTS scoring tools, consisting of two elements, namely the symptom score, and the function examination score.

Hydrodisection injection therapy is the goal of this technique is to place corticosteroids under the flexor retinaculum (ligamentum carpi trans-versum).

The clinical profile of patients in the form of age, gender, occupation, dominant hand will be analyzed descriptively and displayed in the form of frequency and percentage. In this study there were 2 treatment groups, namely patients with triamcinolone injection and normal saline. The dependent variable in the form of pain scale (NPS) and BCTQ will be categorized then compared between the 2 treatment groups. Analysis using unpaired T test. For NPS and BCTQ variables that compare before and after injection will be analyzed using paired T Test. Significance value $p$ $<0.05$ was considered statistically significant. The content consists of research design, data collection, data sources such as the population and sample, and data analysis.

\section{Results}

\section{Characteristics of Research Subjects}

This study involved 30 samples that had met the inclusion criteria and did not get exclusion criteria, and had been scored with NPS and BCTQ before injection and after 4 weeks of injection which were then compared between injection of normal saline (NS) and triamcinolone (TCA). Of the 30 subjects in this study, the average age ranged from 41 to 60 years with a total of 17 patients $(56.67 \%)$. The highest sex of men was 23 patients $(76.76 \%)$. The most dominant hand occurred in the left hand as many as 16 patients $(53.33 \%)$ followed by the right hand of 14 patients (46.67\%). The highest number of jobs was dominated by housewives (IRT) of 10 patients $(33.33 \%)$. The patients came with the most numeric pain scale (NPS) with severe category with 24 patients $(80 \%)$.

In this study the mean age of patients with NS injection was $51.73 \pm 13.66$ years and TCA injection was $47.40 \pm 8.78$ years. There were 5 male patients and 10 female patients in NS injected patients, whereas in TCA injected patients, 2 male patients and 13 female patients. Then there were 7 patients with interference in the right hand and 8 patients with interference in the left hand in patients injected with NS, whereas in patients injected with TCA, 7 people had interference with the right hand and 8 patients with interference in the left hand.

Comparison of characteristics of subjects can also be seen in tables 1 and 2 .

Table 1. Characteristics of Research Data.

\begin{tabular}{|c|c|c|}
\hline Variable & Frequency (n) & Percent (\%) \\
\hline \multicolumn{3}{|l|}{ Age } \\
\hline$<18$ years old & 0 & 0 \\
\hline $18-40$ years old & 8 & 26,67 \\
\hline 41 - 60 years old & 17 & 56,67 \\
\hline$>60$ years old & 5 & 16,67 \\
\hline \multicolumn{3}{|l|}{ Gender } \\
\hline Man & 23 & 76,67 \\
\hline Women & 7 & 23,33 \\
\hline \multicolumn{3}{|l|}{ Hand } \\
\hline Right & 14 & 46,67 \\
\hline Left & 16 & 53,33 \\
\hline \multicolumn{3}{|l|}{ Work } \\
\hline Salon & 2 & 6,67 \\
\hline Online seller & 2 & 6,67 \\
\hline Teacher & 2 & 6,67 \\
\hline Tailor & 2 & 6,67 \\
\hline Cigarette workers & 3 & 10 \\
\hline Medical personnel & 1 & 3,33 \\
\hline IRT & 10 & 33,33 \\
\hline Retired & 2 & 6,67 \\
\hline Baker & 1 & 3,33 \\
\hline Gasstation & 2 & 6,67 \\
\hline workers & 2 & 6,67 \\
\hline Private & 1 & 3,33 \\
\hline \multicolumn{3}{|l|}{ Does not work } \\
\hline \multicolumn{3}{|l|}{ NPS } \\
\hline None (0) & 0 & 0 \\
\hline Mild (1-3) & 0 & 0 \\
\hline Moderate (4-6) & 6 & 20 \\
\hline Severe $(7-10)$ & 24 & 80 \\
\hline
\end{tabular}

Table 2. Data characteristics of injection of normal saline (NS) and triamcinolone (TCA).

\begin{tabular}{llll}
\hline Variable & NS Injection & $\begin{array}{l}\text { TCA } \\
\text { Injection }\end{array}$ & Sig Value \\
\hline $\begin{array}{l}\text { Age, } \\
\text { mean } \pm \text { SD }\end{array}$ & $51.73 \pm 13.66$ & $47.40 \pm 8.78$ & 0.310 \\
Gender & M $: 5$ & M : 2 & 0.390 \\
& F $: 10$ & F $: 13$ & \\
Dominant & RIght $: 7$ & Right $: 7$ & 1.000 \\
Hand & Left $: 8$ & Left $: 8$ & \\
\hline
\end{tabular}

Description: $\mathrm{NS}=$ normal saline; $\mathrm{TCA}=$ triamcinolone; $\mathrm{M}=$ Male; $\mathrm{F}=$ Female; significant $<\alpha(=0.05)$ 


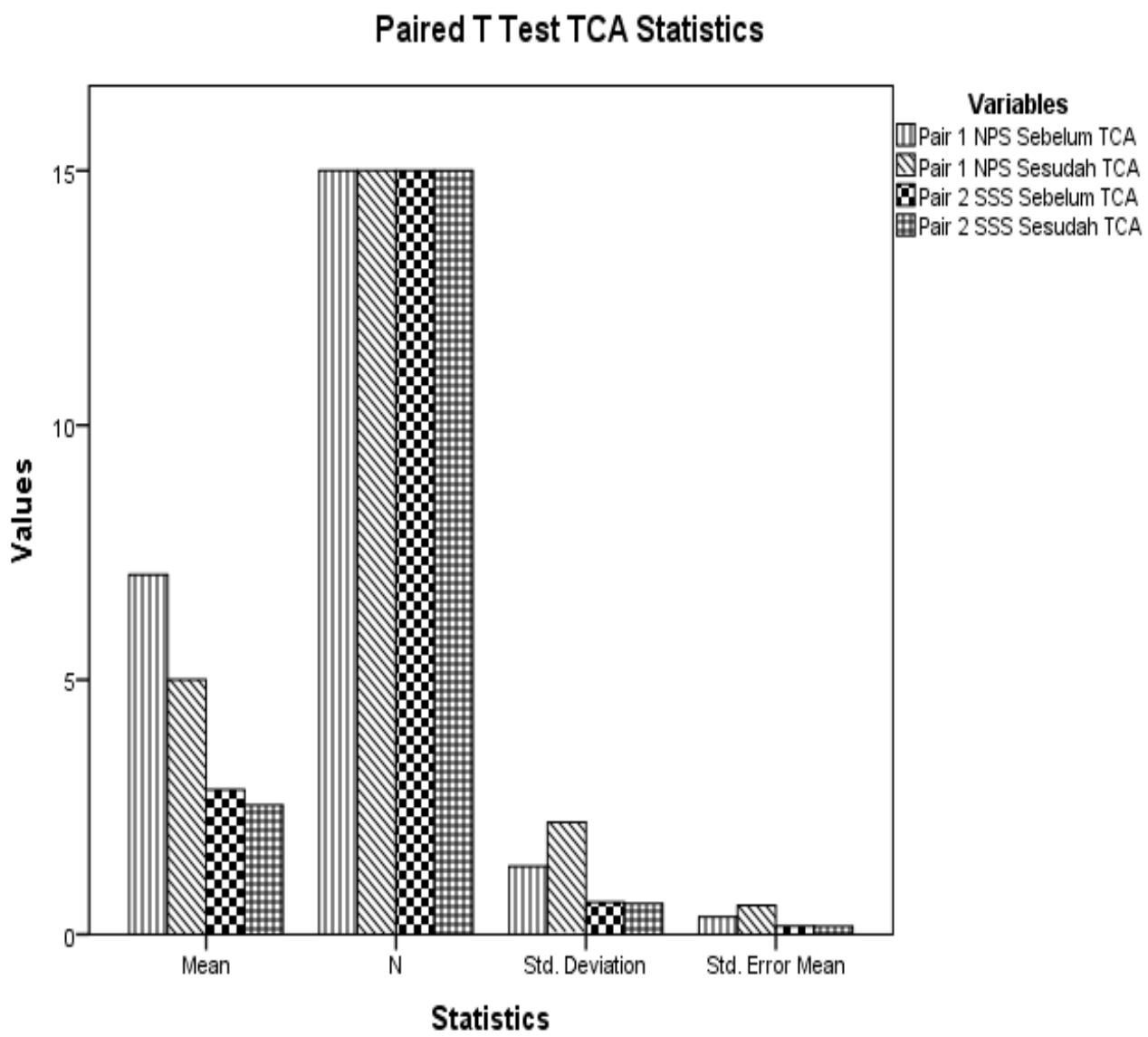

Figure 1. Differences in NPS, FSS and SSS values in patients with TCA injection with paired T tests. NPS = numeric pain scale; SSS = symptom severity scale.

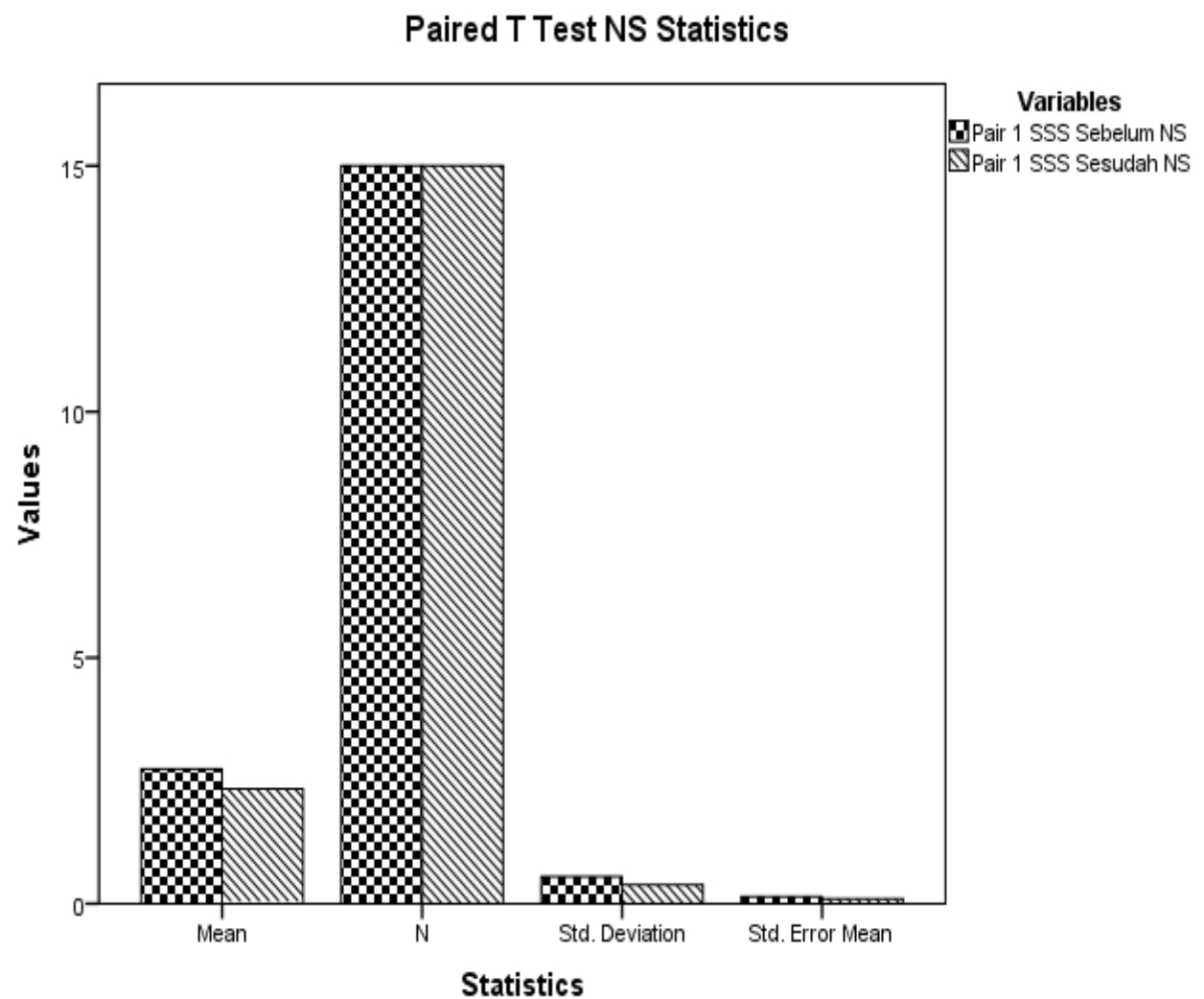

Figure 2. Differences in NPS, FSS and SSS values in patients with NS injection with paired T tests. SSS = symptom severity scale. 


\section{Differences in NPS, FSS and SSS values in patients with TCA injection}

Differences in values before and after injection of FSS SSS NPS in patients with TCA injection all had significant values with the average NPS of patients before injection of TCA $7.06 \pm 1.33$ and after injection of TCA at $5.00 \pm 2.20$. The mean FSS of patients used the Wilcoxon test due to abnormal distribution. The mean SSS of patients before TCA injection was $2.84 \pm 0.93$ and after TCA injection was $2.60 \pm 0.87$. Overall, it can be seen in figure 1 and table 3 .

Table 3. Differences in NPS, FSS and SSS values in patients with TCA injection with the Wilcoxon test.

\begin{tabular}{lccl}
\hline & Z & $\begin{array}{c}\text { Asymp. Sig. } \\
\text { (2-tailed) }\end{array}$ & Description \\
\hline FSS & $-2,332$ & 0.020 & $\begin{array}{l}\text { There are } \\
\text { significant } \\
\text { differences }\end{array}$ \\
\end{tabular}

Description: FSS $=$ functional status scale; $*=$ significant $<\alpha(=$ $0.05)$

\section{Differences in NPS, FSS and SSS values in patients with NS injection}

Differences in values before and after injection of NPS FSS SSS in patients with NS injection all had significant values using the Wilcoxon test for NPS and FSS due to abnormal distribution and unpaired T tests for SSS. The mean SSS of patients before NS injection was $2.74 \pm 0.55$ and after NS injection was $2.33 \pm 0.38$. Overall, it can be seen in figure 2 and table 4.

Table 4. Differences in the value of NPS, FSS and SSS in patients with NS injection with the Wilcoxon test.

\begin{tabular}{lccl}
\hline & $\mathbf{Z}$ & $\begin{array}{c}\text { Asymp. Sig. } \\
\text { (2-tailed) }\end{array}$ & Description \\
\hline NPS & $-3,471$ & 0.001 & $\begin{array}{l}\text { There are } \\
\text { significant } \\
\text { differences }\end{array}$ \\
FSS & $-2,825$ & 0.005 & $\begin{array}{l}\text { There are } \\
\text { significant } \\
\text { differences }\end{array}$ \\
\hline
\end{tabular}

Description: NPS $=$ numeric pain scale; FSS $=$ functional status scale; $*$ = significant $<\alpha(=0.05)$

Differences in NPS, FSS and SSS values in patients with TCA and NS injection

Table 5. The differences in NPS values in TCA and NS injection patients with independent $\mathrm{T}$ tests.

\begin{tabular}{llll}
\hline Variable & $\begin{array}{l}\text { NS Injection, } \\
\text { mean } \pm \text { SD }\end{array}$ & $\begin{array}{l}\text { TCA Injection, } \\
\text { mean } \pm \text { SD }\end{array}$ & $\begin{array}{l}\text { Sig } \\
\text { Value }\end{array}$ \\
\hline NPS & $2.33 \pm 0.38$ & $2.60 \pm 0.87$ & 0.341 \\
\hline
\end{tabular}

Description: $\mathrm{NS}=$ normal saline; $\mathrm{TCA}=$ triamcinolone; $\mathrm{NPS}=$ numeric pain scale; significant $<\alpha(=0.05)$

Table 6. The differences in FSS and SSS values in TCA and NS injection patients with Mann Whitney test.

\begin{tabular}{llll}
\hline Variable & $\begin{array}{l}\text { NS } \\
\text { Injection, } \\
\text { median }\end{array}$ & $\begin{array}{l}\text { TCA } \\
\text { Injection, } \\
\text { median }\end{array}$ & $\begin{array}{l}\text { Sig } \\
\text { Value }\end{array}$ \\
\hline FSS & 14.23 & 16.77 & 0.425 \\
SSS & 14.00 & 17.00 & 0.350 \\
\hline
\end{tabular}

Description: $\mathrm{NS}=$ normal saline; $\mathrm{TCA}=$ triamcinolone; FSS $=$ functional status scale; SSS = symptom severity scale; significant $<\alpha(=0.05)$
Differences in FSS SSS NPS values in patients with NS injection compared with TCA injections all have insignificant values as seen in Table 5 with NPS rates of patients with NS injection of $2.33 \pm 0.38$ and TCA injection of $2.60 \pm 0.87$.

From the homogeneity test we found differences in the calculation of FSS and SSS so that calculations were made using other systems using the Mann Whitney test. The results obtained from the measurements as in table 6 .

Table 6 shows the mean FSS value of patients with NS injection of 14.23 and TCA injection of 16.77. The mean SSS of patients with NS injection was 14.00 and injection of TCA was 17.00.

\section{Discussion}

Average patient is most likely to occur during the reproductive period which carpal tunnel syndrome (CTS) occurs two times more for women than men. ${ }^{1,2}$

In general, the exact cause of CTS causes is still unknown. Repeated activity in the hands is generally thought to be the cause of this syndrome. These risk factors are repetitive movements, high speed movements, uncomfortable joint position, direct pressure on the wrist, vibration, and wrist posture that is maintained for a long time. ${ }^{2}$

\section{Differences in NPS, FSS and SSS in patients with TCA injection}

In this study, NPS, FSS and SSS were examined together before the injection of triamcinolone hydrodisection and after 4 weeks post injection of triamcinolone hydrodisection. Examination of NPS, FSS and SSS is a non-invasive measuring instrument used to assess the degree of symptom improvement that has been proven in various studies such as the research conducted by Lee JY et al (2014).

Until now, not many studies have been reported either in terms of injection techniques or the materials used. One of the studies reported was the research of Lee JY et al (2014), in Seoul, South Korea. In this study CTS patients were obtained with a sample of 45 patients in which there were 15 patients using the same techniques and materials as this study. Of the total 15 patients after being evaluated in 4 weeks, significant improvement was obtained. 3 From these studies significant results were obtained after 12 weeks of observation in which 12 weeks of improvement were obtained gradually, according to the results of this study.

\section{Differences in NPS, FSS and SSS in patients with NS injection}

The results showed that there was a significant difference between the groups of patients who before and after injected hydrodisection of $0.9 \%$ normal saline (NS).

One study that has also been reported is the study of Malone et al (2010) in CTS patients with a sample of 34 patients and 44 wrists. From a total of 34 patients with 44 wrists, after being evaluated in a maximum of 3 weeks, 31 patients were excellent (all complaints were lost / improved), 8 patients were fair (not all disappeared but some complaints improved), and 5 failures (patients needed powder therapy). The results of the Malone et al (2010) study are in accordance with the results in this study. 


\section{Differences in NPS, FSS and SSS in patients with TCA and NS injection}

The study compared patients who were injected with triamcinolone hydrodisection with normal saline $0.9 \% \mathrm{NaCl}$. The technique used is the technique of hydrodisection with the ulnar approach. This technique is based on research that has been done previously by Lee JY et al (2014) in Seoul Korea. From the analytical tests performed, there was no significant relationship between the results of triamcinolone hydrodisection injection and normal saline $0.9 \% \mathrm{NaCl}^{3}$.

For comparison, several other studies regarding the comparison between before and after hydrodisection injection. For example studies of Malone et al (2010), Lee JY et al (2014). Each of these studies gives results that are not much different from the value produced. Both have significant symptom improvements. But the comparison between injection agents is still very rare. Because research on injection agents is still limited to data that can be obtained.

Research on injection agents is still limited in the data that can be obtained regarding injection agents is still very little. Theoretically, the aim of this technique is to place fluid under the flexor retinaculum (ligamentum carpi transversum) and anatomically away from the median nerve, vascular structure, and tendon fibers in a neutral new fluid space made from hydrodisection, to prevent needle penetration and injury from injection of the median nerve, tendon, and vascular structure and allows fluid to be in the hydrodisection space around the tendon sheath flexor digitorum profundus. First, the ulnar bounded palmaris longus tendon is determined. With ultrasound, this position is confirmed by sonography and identification of the median nerve, palmaris longus tendon, radial artery, and ulnar artery with Doppler imaging. Portable ultrasound unit with a 10 to $5 \mathrm{MHz} 38 \mathrm{~mm}$ wide broadband transducer.

The CTS diagnosis in the study was established using history, special neurological examination plus EMG. What is important from this method is that the diagnosis of CTS is established, based on the presence of clinical symptoms in patients such as brachialgia paresthetica nocturna which is a classic symptom of nocturnal paresthesia, but is not pathognomonic for chronic mechanical pressure in the median nerve. At night the patient wakes up feeling thick or swollen in the hand. Finger movements are difficult and slow and interesting pain can be felt along the arm. Sometimes it hurts to the shoulder, even to the back area.

In other words in this study, the samples studied were patients who had experienced neuropathy in the clinical phase. This is supported by EMG examination. This is increase the accuracy in diagnosing and evaluating the prognosis of the injection of triamcinolone hydrodisection and normal saline $0.9 \% \mathrm{NaCl}$.

\section{Conclusion}

In this study, significant reduce of symptom were obtained in NPS, FSS, and SSS before and after injection of hydrodisection with triamcinolone and normal saline 0,9\% $\mathrm{NaCl}$. There no significant difference between injection of hydrodisection USG guiding with triamcinolone and normal saline $0,9 \% \mathrm{NaCL}$ to reduce symptom CTS. So both injection of hydrodisection USG guiding with triamcinolone and normal saline $0.9 \% \mathrm{NaCL}$ has more or less the same effectiveness in treatment of carpal tunnel syndrome.

\section{Acknowledgement}

The researchers would like to acknowledge Department of Neurology and Neurology polyclinic of Dr. Saiful Anwar General Hospital, Malang for supportting this study. The researchers also would like to acknowledge Brawijaya University for supportting this study.

\section{References}

1. KNI Perdossi. Buku modul induk gangguan saraf perifer, gangguan saraf otonom, gangguan paut sarafotot. Indonesia; 2009

2. Laillya N. Neurology in daily parctice. Fakultas Kedokteran Universitas Padjajaran; 2010. Volume 1

3. Lee JY, Park Y, Park KD, Lee JK, Lim OK. Effectiveness of ultrasound-guided carpal tunnel injection using in-plane ulnar approach; A prospective, randomized, single-blinded study. Med (United States); 2014.93(29):e350. 10.1097/MD.0000000000000350

DOI:

4. Purnomo, H. Pain intervention on extra articular rheumatism without usg guidance. Continuing Neurology Education; 2014

5. Makhlouf T, Emil NS, Sibbitt WL, Fields RA, Bankhurst AD. Outcomes and cost-effectiveness of carpal tunnel injections using sonographic needle guidance. Clin Rheumatol; 2014.33(6):849-58. DOI: 10.1007/s10067-013-2438-5

6. Suzanne L et al. Sonographically-guided hydrodissection and corticosteroid injection for scleroderma hand. Clin Rheumatol; 2011. June; 30(6): 805-813. DOI: 10.1007/s10067-010-1653-6

7. Jayadi, Iwan. Tinjauan Pustaka. Indonesia; 2017. Available From: https://docplayer.info/35482802-Babii-tinjauan-pustaka-2-1-terapi-terapi-intravena-ivadalah-menempatkan-cairan-steril-melalui-jarumlangsung.html

8. Malone DG et al. Ultrasound-guided percutaneous injection, hydrodissection, and fenestration for carpal tunnel syndrome: description of a new technique. The Journal of Applied Research; 2010.Volume(10) No. 3. Avalable from: http://www.jarcet.com/articles/Vol10Iss3/Vol10\%20Iss 3Malone.pdf

9. IASP. International Association for the Study of Pain. PAIN. Washington; 2017 Available From: https://www.iasp-pain.org

10. Meliala, L. Terapi rasional nyeri tinjauan khusus nyeri neuropatik edisi pertama. SMF Penyakit Saraf Fakultas Kedokteran Universitas Gadjah Mada-RSUP Dr. Sardjito, Jogjakarta. 2004. ISBN: 979-3589-03-5

11. Numeric Pain Rating Scale. Numeric Pain Rating Scale Instruction; 2019. Available from: https://www.sralab.org/sites/default/files/201707/Numeric\%20Pain\%20Rating\%20Scale\%20Instructi ons.pdf

12. Kurniawan SN. Continuing neurological education 4. UB Press Malang; 2015. Avalable from: 
https://www.researchgate.net/publication/326438503_ NYERI_SECARA_UMUM_GENERAL_PAIN

13. Budisulistyo T. Buku modul prosedur sonoanatomi muskuloskeletal ekstremitas superior dan inferior. Departemen Neurologi Universitas Diponegoro Semarang; 2017

14. Hadinata Y. Perbandingan premedikasi lidokain perlakuan torniket dan campuran lidokain untuk mengurangi derajat nyeri saat induksi anestesi menggunakan propofol di rssa malang. Tesis FKUI Jakarta; 2013. Avalaible from: http://lib.ui.ac.id/file?file=digital/20351659-SPYudi\%20Hadinata.pdf

15. MIMS. Referensi obat informasi ringkas produk obat bahasa indonesia. Bhuana Ilmu Populer Indonesia; 2017

16. Karadas et al. Triamcinolone acetonide vs procaine hydrochloride injection in the management of carpal tunnel syndrome: randomized placebo-controlled trial. J Rehabil Med; 2012.44: 601-4. DOI: 10.2340/16501977-0990

17. FDA. Sodium Chloride 0.9\%. Freeflex; 2010. Available from: https://www.fda.gov/downloads/Drugs/DrugSafety/Dru gShortages/UCM390952.pdf

18. Hadi M, Gibbons E, Fitzpatrick R. A structured review of patient-reported outcome measures for procedures for carpal tunnel syndrome. University of Oxford. UK; 2011. Avalable from: http://phi.uhce.ox.ac.uk/pdf/Carpal\%20tunnel\%20revie w\%20FINAL2013.pdf

19. Kelompok Studi Nyeri Perdossi. Konsensus nasional 1. Diagnostik dan penatalaksanaan nyeri neuropatik. Indonesia; 2011

20. Altman RD et al. Clinical benefit of intra-articular saline as a comparator in clinical trials of knee osteoarthritis treatments: A systematic review and meta-analysis of randomized trials. Elsevier; 2016. DOI: $10.1016 /$ j.semarthrit.2016.04.003

21. Saltzman et al. The therapeutic effect of intra-articular normal saline injections for knee osteoarthritis. The American Journal of Sports Medicine; 2016. Vol.XX, No.X. DOI: 10.1177/0363546516680607

22. Cass SP. Ultrasound-guided nerve hydrodissection: What is it? a review of the literature. Curr Sports Med Rep; 2016.15(1):20-2. DOI: 10.1249/JSR.0000000000000226

23. Trescot A et al. Peripheral nerve entrapment, hydrodissection, and neural regenerative strategies. Elsevier; 2016. DOI: 10.1053/j.trap.2016.09.015

24. Bland JDP. Hydrodissection for treatment of carpal tunnel syndrome. Muscle \& Nerve. Kent and Canterbury Hospital. United Kingdom; 2018.Jan;57(1):4-5. DOI: 10.1002/mus.25759 